\title{
Tough (Water) Justice: Disgorgement as a Remedy for Breach of Interstate Water Compacts
}

\author{
Brendan M. McNeal
}

\section{INTRODUCTION}

"Don't waste water!" is an admonition one might most closely associate with one's childhood. Don't leave the shower on for forty minutes; don't make an artificial river in the street; don't make a mud-pit in the back yard; don't be a wasteful person and don't waste water! And while most have progressed beyond heeding such orders from their parents, each person likely still has a reason for not wasting water. Some may do so to save money, others for the good of the environment, still others because they simply do not like long showers, artificial streetrivers, or mud-pits in their back yards. Regardless, the general understanding is that water is an important resource that-ideallyshould be used conscientiously.

While states may not share the interests that drive people's individual uses of water, they each hold a much broader interest: obtaining enough water for their constituents to use. For western states especially, water is not only as vital to them as it is for their eastern counterparts, but much scarcer as well. ${ }^{1}$ Fewer rivers and less rainfall in the western United States necessitates much more thought and planning for the allocation and use of water resources than is required in states where water is plentiful.

Of course, in the arid west the problem is not just obtaining water, but also sharing it with other states. With aquifers or rivers, states are

\footnotetext{
* J.D. Candidate 2016, University of Kansas School of Law; B.A. 2013, Texas Christian University (Go Frogs!). I would like to thank Davina De La Torre and Professor John Peck for their edits and suggestions throughout the writing of this Comment, Professor Lumen Mulligan for his guidance, and Professor Burke Griggs for his invaluable insights regarding the Kansas v. Nebraska case. I would also like to thank my wonderful family for their continued love, support, (tolerance?), and enthusiasm. And finally, thanks to all my friends at the law school and on the law review, who make law school life a bit more interesting and certainly more enjoyable.

1. See, e.g., Henry Fountain, In California, a Wet Era May Be Ending, N.Y. Times (Apr. 13, 2015), http://www.nytimes.com/2015/04/14/science/californias-history-of-drought-repeats.html (discussing the drought in California, now entering its fourth year, that is "by many measures the worst since the state began keeping records of temperature and precipitation in the $1800 \mathrm{~s}$ ").
} 
obliged to think not only of their needs, but the needs of other states. Theoretically, Colorado could decide to take all Colorado River water originating in the state (about seventy to seventy-five percent of the river's total stream flow $)^{2}$ for its own purposes. Doing so, however, would deprive its downstream neighbors of a major water resource and would likely make sustainable life difficult, if not impossible-enter interstate water compacts.

Like any other contract, an interstate water compact may be breached by a signing state. In the realm of interstate water cases, such breaches tend to occur when a state uses more than its allocated share of water (though states rarely agree on the precise allocated share, or whether a breach even occurred). ${ }^{3}$ Given the uncertainties of rainfall, the needs of constituents, and vagaries in a compact, breaches of interstate compacts are not uncommon, nor are the suits arising from such breaches. ${ }^{4}$ Yet, while a state may breach a water compact, there is by no means a consensus as to how such a breach should be remedied. ${ }^{5}$

Disgorgement is an equitable remedy by which a party is stripped of any profits gained as a result of its wrongdoing. ${ }^{6}$ The question of traditional contract remedies versus disgorgement lies at the heart of two modern water compact cases, ${ }^{7}$ and was one of the major points of contention in Kansas's recent suit against Nebraska. ${ }^{8}$ Central to this question is the overall goal of damages. Are damages intended to make the non-breaching party whole, as is the general goal for breaches of

2. Member States: Colorado, COLORADO RIVER WATER USERS ASSOCIATION (CRWUA), http://www.crwua.org/colorado-river/member-states/colorado (last visited May 24, 2015).

3. See Kansas v. Nebraska, 135 S. Ct. 1042 (2015) (dispute between Kansas and Nebraska regarding allocation of water from the Republican River under the Republican River Compact); Texas v. New Mexico, 482 U.S. 124, 126-29 (1987) (Due to an unclear measurement standard, Texas claimed New Mexico breached the Pecos River Compact by taking more than its allocated share, while New Mexico argued the opposite).

4. See, e.g., Kansas, 135 S. Ct. 1042; Montana v. Wyoming, 131 S. Ct. 1765 (2011) (dispute over allocation of the Yellowstone River); Virginia v. Maryland, 540 U.S. 56 (2003) (dispute over sovereignty and boundaries of the Potomac River); Kansas v. Colorado, 533 U.S. 1 (2001) (dispute over apportionment of the Arkansas River and stating litigation over apportionment dates back to 1902, making this the oldest interstate water dispute in the nation); Texas, 482 U.S. 124.

5. See infra Part II.E-F.

6. JAMES M. FISCHER, UNDERSTANDING REMEDIES 332 (1999).

7. Report of the Special Master, Kansas v. Nebraska, 135 S. Ct. 1042, No. 126 (Me. Nov. 15, 2013), http://www.supremecourt.gov/SpecMastRpt/Org\%20126\%20Jan\%2013\%20Special\%20Mast er\%20Report.pdf [hereinafter Republican Report]; Second Report of Special Master Arthur Littleworth, Kansas v. Colorado, 533 U.S. 1, No. 105 (Sept. 1997), http://www.supremecourt.gov/ SpecMastRpt/ORG105_091997.pdf [hereinafter Ark. River Report].

8. Republican Report, supra note 7, at 10,14. 
contract? $^{9}$ If that is all, what is to prevent a state from committing efficient breach over and over again, so long as it is willing to pay the expectation damages? Or should damages not only make a party whole, but also seek to prevent future breaches through the remedy of disgorgement (stripping the breaching state of any profits it may have gained through its breach)? ${ }^{10}$ If this is the goal, how extensive should the punishment be? Should the same damages apply for every breach, or should disgorgement vary with the extent of the breach itself?

Part II of this Comment begins by examining the general procedure for resolving interstate water disputes, specifically the roles of the Supreme Court and "special masters" respectively. It then moves on to the general rules for remedying breaches of contract, as found in the Restatement (Second) of Contracts, ${ }^{11}$ and then examines the varying theories for applying disgorgement in certain cases. Finally, Part II provides an overview of important water disputes between states, with special emphasis on the disgorgement question in Kansas v. Nebraska.

Part III of this Comment analyzes both the Supreme Court's and the Special Master's disgorgement findings in Kansas v. Nebraska. It argues that disgorgement should be applied to breaches of interstate water compacts in order to stabilize those compacts and also protect downstream states. Finally, Part III proposes a five-factor test with which to measure the severity of a breach and determine the extent to which disgorgement should be applied against a breaching state.

\section{BACKGROUND}

\section{A. Supreme Court Practice for Original Actions}

Interstate water compacts are contractual agreements between states allocating common water resources. What makes these compacts peculiar is their allocation of resources that are irreplaceable and usually vital. ${ }^{12}$ Water compacts seek to distribute water equitably to both upriver (upstream) and downriver (downstream) states. Upstream states have the benefit of prior access to water along a river, and therefore are almost

9. See 3 Dan B. Dobbs, Law of Remedies: Damages, Equity, Restitution 5 ( $2 \mathrm{~d}$ ed. 1993) ("[T]he aim of damages is compensation for the plaintiff"s loss, or at least some substitute for compensation.").

10. See Restatement (ThiRd) of Restitution and UnJust EnRichment § 39 (2011); Andrew Kull, Disgorgement for Breach, the "Restitution Interest," and the Restatement of Contracts, 79 TEX. L. REV. 2021, 2050 (2001).

11. ReStatemENT (SECOND) OF CONTRACTS $\S \S 344-56$ (1981).

12. Kansas v. Nebraska, 135 S. Ct. 1042, 1057 (2015). 
always defendants in a water dispute. Downstream states, on the other hand, must rely on the compliance of an upstream state to receive their own water. It is generally downstream states that initiate legal proceedings.

Many compacts, like the Republican River Compact between Kansas, Nebraska, and Colorado, are submitted to Congress and thereafter become formal U.S. law. Because the compacts are among states, any disputes arising from the compacts are adjudicated as an original action before the Supreme Court. ${ }^{13}$ This procedure is described in the sections below.

\section{Original Actions Generally}

By their very nature, original action cases arrive at the Supreme Court without prior lower court litigation. ${ }^{14}$ Court authority to hear original cases derives from Article III, Section 2 of the U.S. Constitution, which states that the judicial power shall extend to, among other things, "controversies between two or more states." 15 This authority is also codified at 28 U.S.C. $\S 1251$, which states, "The Supreme Court shall have original and exclusive jurisdiction of all controversies between two or more States." While it has the power to adjudicate other claims, the majority of original action cases heard by the Supreme Court are disputes among the states. ${ }^{17}$ In such cases, the Court has jurisdiction regardless of whether a federal question is at issue or whether the dispute arises out of state or federal law. ${ }^{18}$ It is a general proposition that, because the states have individually ratified the Constitution (that is, consented to its provisions), the Court has the power to adjudicate all disputes among the states. ${ }^{19}$ Even though the Court has the power to adjudicate disputes does not necessarily mean it will.

Original jurisdiction is discretionary. ${ }^{20}$ To obtain jurisdiction, a state must file a complaint with the Court, preceded by a motion for leave to file suit, which "may be accompanied by a brief in support of the

\footnotetext{
13. U.S. CONST. art. III, § 2, cl. 1-2; see also 22 JAMES WM. MOORE ET AL., MOORE'S Federal PRACTICE 902.03 (3d ed. 1999).

14. Stephen M. Shapiro et Al., Supreme Court Practice $\S 10.1$ (10th ed. 2013).

15. U.S. CONST. art. III, $\S 2$, cl. 1.

16. 28 U.S.C. $\S 1251(a)(2012)$

17. SHAPIRO ET AL., supra note $14, \S 10.2$.

18. MOORE ET AL., supra note 13.

19. Id.

20. Id.
} 
motion." 21 Opposing states may then file briefs in opposition stating why Supreme Court jurisdiction is not proper in the present case. ${ }^{22}$ In deciding whether to hear the case, the Court will consider the interests of the complaining state and the seriousness of the claim, as well as whether any alternative forums exist in which to resolve the dispute. ${ }^{23}$ Most frequently, the Court will hear sovereignty and property cases, including interstate water disputes. ${ }^{24}$ For disputes requiring a complex factual inquiry (practically every interstate dispute), the Supreme Court does not act as a trial court, but instead appoints a special master to hear evidence, grant motions, and so forth. ${ }^{25}$

\section{Special Masters}

A special master has all the essential dressings of a trial judge: he may conduct extensive evidentiary hearings, listen to oral arguments, and make general findings of fact. ${ }^{26}$ Usually, special masters have an extensive background in the disputed field and may be attorneys, professors, or retired judges. ${ }^{27}$

At the conclusion of proceedings, the special master will describe his findings in a report submitted to the Supreme Court. ${ }^{28}$ The findings are merely advisory and subject to exceptions by the states, which file those exceptions - or responses to exceptions - in briefs to the Court. ${ }^{29}$ The Court serves as the final decision-maker in an interstate dispute, hearing any critical motions and ultimately deciding the extent to which it accepts the findings of the master or exceptions of the states. ${ }^{30}$

The Court's jurisdiction in interstate disputes is "basically equitable in nature." ${ }^{31}$ Exercising its jurisdiction, then, the Court will vary in its application of state, federal, or general common law depending on the particular action. $^{32}$ In cases involving an interstate compact, the Court

\footnotetext{
21. SUP. CT. R. 17.3; see also SHAPIRO ET AL., supra note $14, \S 10.7$.

22. SUP. CT. R. 17.5; see also SHAPIRO ET AL., supra note $14, \S 10.7$.

23. MOORE ET AL., supra note 13, \ 402.03(5).

24. SHAPIRO ET AL., supra note $14, \S 10.2$.

25. Id. $\S 10.11$.

26. MOORE ET AL., supra note 13, ๆ 402.05(2)(b).

27. Id.

28. SHAPIRO ET AL., supra note $14, \S 10.12$.

29. Id.

30. MOORE ET AL., supra note 13, - 402.05(2)(b)

31. Ohio v. Kentucky, 410 U.S. 641, 648 (1973).

32. MOORE ET AL., supra note 13, 『 402.05(2)(c).
} 
generally examines the compact itself to help construe the agreement and to fashion an appropriate remedy. ${ }^{33}$

\section{B. Disgorgement as a Remedy}

Apart from determining whether a state has indeed breached a water compact, the Supreme Court has grappled with just how to remedy water disputes. $^{34}$ In the 1987 case of Texas $v$. New Mexico, the Court indicated that money damages would be a sufficient remedy for the breach of an interstate water compact. ${ }^{35}$ With this holding, several other questions necessarily arise, most importantly: If money damages may be sought, should those damages focus solely on making a state whole through expectation damages, or also seek to prevent future breaches through disgorgement? Before fully answering this question, one must understand the disgorgement remedy, as well as its traditional uses. This section canvases disgorgement as described in the Restatement (Third) of Restitution and Unjust Enrichment, gives a brief clarification of "restitution," and, finally, examines disgorgement's traditional uses.

\section{Disgorgement Defined}

Section 3 of the Restatement (Third) of Restitution and Unjust Enrichment states, "[a] person is not permitted to profit by his own wrong." 36 And, additionally, the "conscious wrongdoer" is liable to disgorge all profits obtained from his wrongdoing. ${ }^{37}$ Section 51 of the Restatement maintains that the ultimate goal of disgorgement (or restitution, discussion of terms below) is to avoid imposing a penalty on a defendant while still eliminating any profit gained by his wrongdoing. ${ }^{38}$

The Restatement suggests four separate instances in which disgorgement may be applied against a defendant: (1) breach of fiduciary duty, (2) breach of contract with a tort, (3) equitable conversion, and (4) "opportunistic" breach of contract. ${ }^{39}$ When there is a breach of fiduciary duty, disgorgement may be applied to prevent a fiduciary from profiting from his breach of that duty. ${ }^{40}$ Breach of contract with a tort speaks for

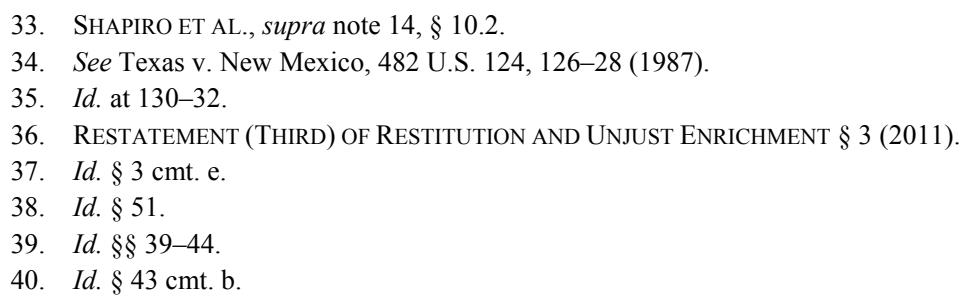


itself, since disgorgement applies when a tort accompanies the breach of some contractual agreement. ${ }^{41}$ In the case of equitable conversion, the Restatement states that any person "who obtains a benefit by an act of trespass or conversion" will be liable for disgorgement and stripped of all profits resulting from his interference with the plaintiff's property. ${ }^{42}$ Opportunistic breach of contract provides the most interesting scenario. The Restatement states that disgorgement may be sought as an alternative remedy if regular damages do not adequately protect the plaintiff's interests, or when it is not possible for the plaintiff to obtain an equivalent good or performance. ${ }^{43}$ Disgorgement in such a case eliminates the possibility that a party will gain more from a breach than a negotiation. ${ }^{44}$ Each of these scenarios will be discussed in further detail below in section $\mathrm{D}$.

\section{2. "Restitution" Versus "Disgorgement"}

In the contractual sense, "restitution" means the "restoration of the plaintiff to his pre-contractual position." 45 On the other hand, "restitution" in the unjust enrichment sense is merely "disgorgement" under a different name - that is, depriving a defendant of his wrongful gains. ${ }^{46}$ Adding to the confusion, the Restatement (Second) of Contracts appears to endorse the former definition, while the Restatement (Third) of Restitution and Unjust Enrichment favors the latter. ${ }^{47}$ In this Comment, "restitution" will be deemed synonymous with "disgorgement," unless expressly stated otherwise.

\section{Traditional Purposes of Disgorgement}

As an equitable remedy, disgorgement has traditionally sought to deter violations of the law - or contracts - by depriving wrongdoers of their ill-gotten gains, thereby making violations unprofitable. ${ }^{48}$ Disgorgement applies the general principle that one should not profit

\footnotetext{
41. Id. $\S 44$.

42. Id. $\S 40 \mathrm{cmt} . \mathrm{b}$.

43. Id. $\S 39(1)$ (Disgorgement may be an alternative remedy for breach of contract if the usual remedy "affords inadequate protection to the promisee's contractual entitlement.").

44. Id. $\S 39(1) \mathrm{cmt}$. e.

45. Kull, supra note 10, at 2028-29.

46. Id.

47. Id. at 2037-39; see also Restatement (ThiRd) OF Restitution AND UnJUst ENRICHMENT ch. 4, topic 2, intro. note (2011).

48. FISCHER, supra note 6 , at 332 .
} 
from his wrongdoing. ${ }^{49}$ The main goal of this remedy, then, is not compensation, but deterrence. ${ }^{50}$

Disgorgement is limited only to profits directly relating to the wrongdoing. ${ }^{51}$ While the Restatement (Third) of Restitution and Unjust Enrichment mentions it as a possible remedy for breach of contract, ${ }^{52}$ courts seemingly limit disgorgement to breaches of fiduciary duty, unjust taking of property (equitable conversion), or when a party has committed a tort while breaching a contract. ${ }^{53}$

\section{Remedies for Breach of Contract}

Disgorgement is an odd creature in the world of remedies, and practically unheard of in breach of contract cases. This section briefly explores traditional contract remedies - from which disgorgement is notably absent. Thereafter, this section covers the most common of contract remedies, expectation damages, and lastly, it examines the traditional view that contract remedies should not punish the offending party.

1. Traditional Remedies

Damages for breach of contract typically aim at compensating the plaintiff, not punishing the defendant. ${ }^{54}$ As stated in the Restatement (Second) of Contracts, contract remedies traditionally protect a plaintiff's "expectation interest" (plaintiff put in as good a position as if the contract had been performed), "reliance interest" (plaintiff reimbursed for losses caused in reliance on the contract), or "restitution interest" (restoring a plaintiff to his pre-contract status). ${ }^{55}$ Disgorgement notably does not appear as a traditional remedy in the Restatement. ${ }^{56}$

49. John D. McCamus, Disgorgement for Breach of Contract: A Comparative Perspective, 36 LOY. L.A. L. REV. 943, 945 (2003).

50. FISCHER, supra note 6 , at 333.

51. RESTATEMENT (THIRD) OF RESTITUTION AND UNJUST ENRICHMENT § 51(4) (2011).

52. Id. $\S 39$

53. McCamus, supra note 49, at 951-52.

54. DoBBS, supra note 9, at 5; RESTATEMENT (SECOND) OF CONTRACTS $\S 355 \mathrm{cmt}$ a (1981).

55. RESTATEMENT (SECOND) OF CONTRACTS $§ 344$ (1981).

56. See id. $\S 345,347$. 


\section{Expectation Damages}

Expectation damages are the most favored type of contract damages. ${ }^{57}$ Courts generally calculate expectancy by determining the market value of the product or service (at the time of breach) less the value of the contract. ${ }^{58}$ Thus, if a plaintiff contracts to purchase goods for $\$ 10,000$, and the defendant reneges on the contract when the market value of replacement goods is $\$ 20,000$, the plaintiff receives $\$ 10,000$ in damages - since he would not have had to pay an additional $\$ 10,000$ for a replacement had the defendant adhered to the contract. ${ }^{59}$

The theory of efficient breach explains the appeal of expectation damages for traditional breaches of a contract. Generally speaking, the idea behind efficient breach is that contracts should encourage economic activity. ${ }^{60}$ Expectation damages encourage compliance with a contract until the point at which breach becomes more profitable. ${ }^{61}$ In other words, efficient breach theory encourages a party to comply until the point at which it can pay full expectation damages and still net a profit. $^{62}$

\section{No Punitive or Restitutionary Damages for Breach of Contract}

At common law, punitive damages are not an available remedy in breach of contract cases - even in cases of willful or malicious breachunless there is an independent tort involved. ${ }^{63}$ The rationale for this rule arises out of efficient breach theory: Parties should be allowed to breach contracts so long as the plaintiff is placed in his rightful position. ${ }^{64}$ Applying this theory to disgorgement, a party who breached a contract would not have to disgorge the profits gained from its breach, so long as the plaintiff obtained a full recovery. ${ }^{65}$ Efficient breach theory would balk at the notion that an economically sensible party should give up its profits when the plaintiff has been fully compensated. ${ }^{66}$

\footnotetext{
57. Id. $\S 347$; DoBBS, supra note 9 , at 25 .

58. DoBBs, supra note 9 , at 6 .

59. Id. at 25.

60. Id. at 26

61. Id. at 27

62. $I d$.

63. Id. at 117-18; see also RESTATEMENT (SECOND) OF CONTRACTS § 355 (1981).

64. DoBBS, supra note 9, at 119.

65. Id. at 171 .

66. Id. at 173 .
} 


\section{Disgorgement for Breach of Contract?}

As the above sections demonstrate, disgorgement for breach of contract enjoys very little precedent as a traditional contract remedy. Nevertheless, there are interesting possibilities for applying disgorgement in at least some breach of contract situations-including interstate water disputes. Four particular scenarios exist in which a court could, at least theoretically, apply disgorgement: (1) breach of fiduciary duty, (2) breach of contract combined with a tort, (3) equitable conversion, and (4) opportunistic breach. ${ }^{67}$

\section{Breach of Fiduciary Duty ${ }^{68}$}

The basic premise for providing disgorgement for breach of fiduciary duty is the nature of the relationship. Because a party relies upon a fiduciary to fulfill his duty in good faith, any breach of that reliance is treated as an especially egregious moral wrong, from which the fiduciary should not be allowed to profit. ${ }^{69}$ The extent of disgorgement in such cases depends in large part upon "the nature of the... violation" (whether the fiduciary went completely against the interests of the reliant party), and whether the fiduciary breached deliberately or accidentally. ${ }^{70}$

\section{Breach of Contract with Tort ${ }^{71}$}

Breach of a contract with an accompanying tort is rather selfexplanatory. The scenario arises when a party interferes with a contract to such an extent that the interference becomes a tort. ${ }^{72}$ Disgorgement in this scenario would strip the offending party of all profits resulting from its tortious act. ${ }^{73}$

\section{Equitable Conversion ${ }^{74}$}

Equitable conversion presents an interesting situation. The essential scenario is one in which a seller of property agrees to sell to a buyer, and

\footnotetext{
67. RESTATEMENT (THIRD) OF RESTITUTION AND UNJUST ENRICHMENT $§ 39 \mathrm{cmt}$. d (2011).

68. See id. $\S \S 41-43$.

69. Id. $\S 43 \mathrm{cmt}$. b; FISCHER, supra note 6 , at 647.

70. FISCHER, supra note 6, at 648.

71. See generally RESTATEMENT (THIRD) OF RESTITUTION AND UNJUST ENRICHMENT $\S 44$.

72. Id. § 44 cmt. b.

73. Id.

74. See id. $\S 40$.
} 
the buyer then becomes the owner of that property only to then have the seller deprive the buyer of the property in some way. ${ }^{75}$ In other words, the defendant-seller takes the plaintiff-buyer's property for his own profit. $^{76}$

For example: A buys land from B for the express purpose of using gravel from that land, and with the stipulation that B not use it in any way. However, before A takes possession of the land, B takes all the gravel and sells it. Disgorgement in this case would strip B of the profits gained from his breach of contract and subsequent conversion. ${ }^{77}$ The determination of whether disgorgement should be applied in an equitable conversion case very much depends on the defendant's state of mind. ${ }^{78}$ A defendant who mistakenly took property may not have to disgorge his profits, while a defendant who knowingly took property almost certainly will. $^{79}$

\section{Opportunistic Breach ${ }^{80}$}

An alternative theory regarding disgorgement as a contract remedy applies in cases of opportunistic breach. Opportunistic breach is a mirror image of efficient breach insofar as both concern a scenario in which a party consciously breaches its contract for economic motives. ${ }^{81}$ Efficient breach, however, envisions a scenario in which the subject of the contract (whether that be a good, service, or other property) is easily replaceable, and for which a breach can be remedied by expectation damages. ${ }^{82}$

Opportunistic breach concerns itself with a contract "in which the promisee's contractual position is vulnerable to abuse." 83 According to the Restatement (Third) of Restitution and Unjust Enrichment, a contract's vulnerability derives "from the difficulty that the promisee may face in recovering . . . a full equivalent of the performance for which the promisee has bargained." $" 84$ Thus situated, the promisor could make the self-serving determination that it would be more profitable to breach

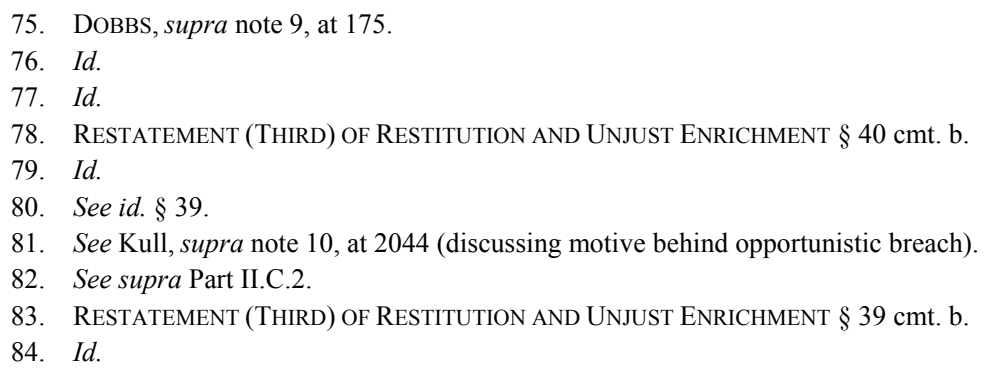


the contract than to perform it or negotiate a new one. ${ }^{85}$ The promisee, then, would face the unenviable task of finding a replacement for a rare - maybe irreplaceable - good or performance, with a damages claim that is minimal compared to the breaching party's profits. ${ }^{86}$

In a case of opportunistic breach, either the plaintiff does not receive what it has already paid for, or the defendant obtains a profit by doing precisely what it has contracted not to do. ${ }^{87}$ Disgorgement seeks to defeat this process by making breaches unprofitable. ${ }^{88}$ Additionally, disgorgement looks to stabilize the contractual relationship between the two parties and incentivize renegotiation of the contractual terms, thereby minimizing the uncertainty that a party might renege for more favorable opportunities. ${ }^{89}$

\section{Arguments Against Disgorgement}

The traditional issue with disgorgement as a contract remedy is that the plaintiff in such a case often recovers more than it has lost. ${ }^{90}$ Any additional disgorgement recovery merely serves to penalize a breaching party, and thus encounters the Restatement (Second) of Contracts' prohibition against punitive damages in breach of contract cases. ${ }^{91}$ Disgorgement also runs contrary to the theory of efficient breach. Such a remedy would disincentivize what is regarded - at least by economistsas a healthy market activity.

\section{E. Important Interstate Water Cases for Remedies}

The Supreme Court has heard and decided numerous interstate water disputes under its original jurisdiction - though, cases involving water compacts are relatively new. ${ }^{92}$ While each case is individually significant, two particular actions stand out as important in the realm of

85. Kull, supra note 10, at 2049.

86. RESTATEMENT (THIRD) OF RESTITUTION AND UNJUST ENRICHMENT $\S 39 \mathrm{cmt}$. b.

87. See Kull, supra note 10, at 2045.

88. Restatement (THiRD) OF RESTITUTION AND UNJUSt ENRICHMENT $\S 39 \mathrm{cmt}$. b.

89. Id.; Kull, supra note 10, at 2050.

90. Kull, supra note 10, at 2030-31.

91. Id.; see supra Part II.C.3.

92. See, e.g., Kansas v. Nebraska, 135 S. Ct. 1042 (2015) (compact case); Montana v. Wyoming, 131 S. Ct. 1765 (2011) (compact case); Texas v. New Mexico, 482 U.S. 124 (1987) (first case based on a water compact dispute); Nebraska v. Wyoming, 325 U.S. 589 (1945) (equitable apportionment case); Kansas v. Colorado, 185 U.S. 125 (1902) (the Court solved the 1902 dispute on equitable apportionment grounds, more recent disputes have been decided based on the Arkansas River Compact). 
remedies for interstate water disputes and the potential application of disgorgement: Texas v. New Mexico (the Pecos River Compact) and Kansas v. Colorado (the Arkansas River Compact).

\section{Texas v. New Mexico: Money Damages for Water Disputes}

The Pecos River case between Texas and New Mexico is a foundationally important case for remedies in compact breach because, first, it allowed for money damages in water disputes, and, second, left interesting language regarding the Court's power to apply disgorgement remedies in the future. The dispute arose when Texas alleged New Mexico had taken more than its allotted share under the Pecos River Compact. $^{93}$ The Court appointed a Special Master, who found New Mexico had violated the Compact, but recommended that New Mexico pay damages in water. ${ }^{94}$ The Supreme Court ruled money damages could be applied to water disputes, but left the precise dollar amount to the Special Master. ${ }^{95}$

Several statements in the Court's opinion left open the possibility for disgorgement in future cases. First, the Court stated that its authority "to order remedying shortfalls to be made up in kind, with whatever additional sanction might be thought necessary" foreclosed the possibility that states would use money sanctions to ignore compact compliance. ${ }^{96}$ Additionally, the Court noted that its power to hear original actions gave it the authority to provide a "fair and equitable solution that is consistent with the Compact terms.",97

While several similar statements exist, the two mentioned above give the general groundwork for a disgorgement argument. First, that disgorgement could be necessary to ensure compliance when it appears traditional contract remedies will not suffice. Second, that it is within the Court's equitable jurisdiction to render such a judgment. ${ }^{98}$

93. Texas v. New Mexico, 482 U.S. 124, 126-27 (1987).

94. Id. at $127-28$.

95. Id. at $129-32$.

96. Id. at 132 .

97. Id. at 134 .

98. Exceptions by Plaintiff State of Kansas to the Report of the Special Master and Brief in Support of Exceptions at 35-36, Kansas v. Nebraska, 135 S. Ct. 1042 (2015), No. 126 (Oct. 14, 2014), http://www.americanbar.org/content/dam/aba/publications/supreme_court_preview/BriefsV4/ Orig126_exceptions_state_of_kansas.authcheckdam.pdf [hereinafter Kansas Exceptions]. 
2. Kansas v. Colorado: Disgorgement in the Right Circumstances?

The Arkansas River case between Kansas and Colorado provides another field for the disgorgement debate, though the authority here is not as strong. Kansas and Colorado's dispute over the Arkansas River dates to 1902, but the notable instance occurred in more recent litigation. Modern disputes have, among other things, involved the issue of whether Colorado breached the Arkansas River Compact by over-pumping groundwater. ${ }^{99}$ In his report, Special Master Arthur Littleworth reviewed Kansas's suggestion that disgorgement be applied. While he dismissed the possibility in that instance, the Special Master did note that he had "no doubt about the power of equity to provide complete relief, perhaps even looking to upstream gain under appropriate circumstances." 100 This language, though in the context of denying disgorgement, suggested that disgorgement could be used in a water compact case in the correct circumstances, an argument Kansas adopted in its case against Nebraska. ${ }^{101}$

\section{F. Kansas v. Nebraska: The Modern Push for the Disgorgement Remedy in Water Disputes}

The action between Kansas and Nebraska was a dispute over disgorgement, only recently decided by the Supreme Court. The case involved the apportionment of Republican River water between Kansas, Colorado, and Nebraska-with Kansas as the downstream state. The Republican River begins in Colorado, crosses the northwest corner of Kansas, and then meanders through western and central Nebraska before reentering north-central Kansas. ${ }^{102}$ Overall, the Republican River Basin spans about 430 miles and drains an approximately 24,000 square-mile watershed. ${ }^{103}$

This section first describes the Republican River Compact between Colorado, Kansas, and Nebraska, touching briefly on the relevant provisions. Next, it reviews the first action regarding the Compact, which began in 1999, and resulted in the all-important Final Settlement Stipulation (FSS). The section closes with an examination of the action that commenced in 2010, with descriptions of the Special Master's

\footnotetext{
99. Kansas v. Colorado, 533 U.S. 1, 4-6 (2001).

100. Ark. River Report, supra note 7, at 82.

101. See Kansas v. Nebraska, 135 S. Ct. 1042 (2015).

102. Republican Report, supra note 7, at 2.

103. Id. at $2-3$.
} 
findings, the exceptions of both Kansas and Nebraska, and finally, the Supreme Court's decision.

1. The Republican River Compact: Water Apportionment between Colorado, Kansas, and Nebraska

In 1943, Kansas, Colorado, and Nebraska created the Republican River Compact, ${ }^{104}$ which apportions the waters of the Republican River between the three states. ${ }^{105}$ Specifically, the Compact allocates "virgin water supply" of the river, ${ }^{106}$ that is, "water supply within the Basin undepleted by the activities of man." 107 Water is allocated for "beneficial consumptive use," 108 which is use "by which the water supply of the Basin is consumed through the activities of man."109 To aid compliance, the three states created the Republican River Compact Administration (RRCA) in 1959, comprised of three members - one from each statewho unanimously calculate the Basin's virgin water supply each year. ${ }^{110}$ Interpretation of this Compact lies at the heart of the recent dispute.

\section{Round One: A New Way to Measure Compliance}

The first action commenced in 1999 when Kansas alleged that Nebraska had exceeded its apportioned amount by allowing thousands of unregulated wells to pump in the Republican River Basin. ${ }^{111}$ Nebraska responded that the Compact did not cover groundwater pumping, and thus it should not be counted against the state's allocated share under the

104. Republican River Compact, Pub. L. No. 78-60, 57 Stat. 86 (1943) [hereinafter RP Compact].

105. Republican Report, supra note 7, at 2.

106. RP Compact, supra note 104 , art. III.

107. Id. art. II.

108. Id. art. IV

109. Id. art. II.

110. Republican Report, supra note 7, at 4.

111. Id. at 5. It is worth noting that the major premise in this case was that, by pumping, the wells were depleting the "stream flow" of the Republican River. Id. That is to say, over-pumping caused water that would normally flow downriver to instead seep into the ground. The best way to imagine this scenario is to think of a sponge next to a small stream of water. When the sponge is saturated, the stream of water will simply flow by. However, if the sponge is relatively dry, more water will soak into it, decreasing the amount of water that will continue downstream. The same concept applies to groundwater pumping in a river basin. THOMAS C. WINTER ET AL., U.S. Geological Survey, U.S. DeP'T of THE InTERIOR, Circular No. 1139, Groundwater AND SURFACE WATER: A SINGLE RESOURCE 14-15 (1998), http://pubs.usgs.gov/circ/circ1139/ pdf/circ1139.pdf. 
RRCA. $^{112}$ The Special Master ruled against Nebraska, after which the three states entered into negotiations to determine how to calculate stream flow, pumping, and other factors. ${ }^{113}$ The states eventually produced the Final Settlement Stipulation (FSS), which the Supreme Court approved in 2003. ${ }^{114}$

The FSS combines several different models to calculate water supply and usage in the Republican River Basin. ${ }^{115}$ Compliance under the FSS is measured on running averages: a five-year average in normal years ("normal" administration), or a two-year average in drought years ("water short" administration). ${ }^{116}$ Thus, a state that exceeds its allocated amount one year can still comply with the Compact—so long as it consumes less water in subsequent years, thereby bringing its average consumptive use to compliance levels. ${ }^{117}$

\section{Round Two: Disgorgement Has Its Day in Court}

The recent case commenced in 2010 when Kansas filed a motion for leave to file with the Supreme Court. ${ }^{118}$ Kansas alleged Nebraska had breached the FSS by taking more than its allocated share in both 2005 and 2006 (which happened to be a "water short" administration period) and calculated Kansas's expectation damages at just over $\$ 5$ million. ${ }^{119}$ Additionally, Kansas alleged Nebraska had obtained a substantial profit - an estimated $\$ 62$ million - through its breach, and asked for disgorgement to deter against future breaches. ${ }^{120}$

In its reply, Nebraska conceded Compact violations in 2006, but disputed the overall amount by which it had exceeded its allocated share. ${ }^{121}$ Nebraska pointed to both the extreme drought conditions in

\footnotetext{
112. Republican Report, supra note 7, at 5.

113. Id. at 5-6.

114. Id. at 6 .

115. Id. at 8 .

116. Id.

117. See id. ("[C]ompliance with the Compact's allocation limits is determined based on multiyear running averages in order to smooth out year-to-year deviations and to provide the parties with increased flexibility.").

118. Motion for Leave to File Petition, Petition, and Brief in Support at 1, Kansas v. Nebraska, 135 S. Ct. 1042 (2015), No. 126 (N.M. May, 2010), http://sblog.s3.amazonaws.com/wp-content/ uploads/2010/10/Pet.126org.pdf [hereinafter Kansas Motion].

119. Id. at 9-10; Republican Report, supra note 7, at 138.

120. Kansas Motion, supra note 118, at 10,12; Republican Report, supra note 7, at 172.

121. Brief of the State of Nebraska in Response to Kansas' Motion for Leave to File Petition at 2-7, Kansas v. Nebraska, 135 S. Ct. 1042 (2015), No. 126 (July 1, 2010), 2010 WL 10807843.
} 
2002-2006 and its recent efforts to achieve full compliance as evidence that disgorgement was unnecessary in the circumstances. ${ }^{122}$

This section reviews the Special Master's findings, the exceptions of Kansas and Nebraska, and the Supreme Court's recent decision. For his part, the Special Master ultimately found that Nebraska had breached the Compact and owed Kansas relatively light disgorgement and expectation damages. ${ }^{123}$ Kansas generally agreed with the Special Master-at least on the disgorgement matter-but objected to the small disgorgement award. ${ }^{124}$ Nebraska took the opposite view and excepted the disgorgement finding on the basis that the remedy had no precedent in contract law. ${ }^{125}$ The United States, in its amicus brief to the Supreme Court, fully supported the Special Master's findings and urged the Court to reject the states' exceptions. ${ }^{126}$ The Supreme Court, in its decision on the case, fully accepted the Special Master's disgorgement findings and rejected all state exceptions. ${ }^{127}$

\section{a. The Special Master's Findings}

Special Master William Kayatta, Jr. generally agreed with Kansas's loss calculations in his findings, though he noted that Kansas had most likely overestimated its 2005 damages. ${ }^{128} \mathrm{He}$ therefore concluded Kansas's losses amounted to $\$ 3.7$ million. ${ }^{129}$ The Special Master also concluded Kansas had overestimated the total gain received by Nebraska, though he noted it almost certainly exceeded Kansas's loss. ${ }^{130}$ Ultimately, Special Master Kayatta determined that Nebraska had exceeded its allocated share of water by 70,869 acre-feet (about seventeen percent more than its apportioned amount). ${ }^{131}$

To calculate Nebraska's actual gain, the Special Master found that the state had spent approximately $\$ 18.7$ million on about 98,000 acrefeet $^{132}$ of water between 2006 and $2008 .{ }^{133}$ With those numbers, the

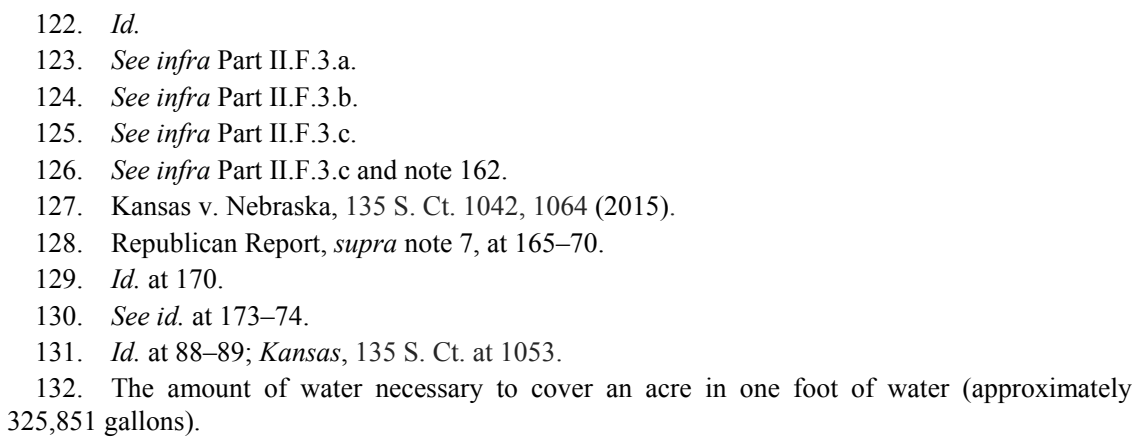


Special Master calculated the average value of water in the Basin (during the 2006-2008 period) to be $\$ 362$ per acre-foot. ${ }^{134}$ He then multiplied this value by Nebraska's estimated overuse (70,869 acre-feet), and thereby estimated Nebraska had gained over \$25 million from its breach (he did, however, note that a lack of evidence made an exact calculation impossible). ${ }^{135}$ Overall, the Master concluded Nebraska gained a great deal more than Kansas lost, and recommended \$3.7 million in expectation damages and $\$ 1.8$ million in disgorgement (providing no procedure for his disgorgement calculation). ${ }^{136}$

To support his disgorgement finding, the Special Master looked to Nebraska's approach to FSS compliance between 2002 and $2006 .^{137}$ After it agreed to the FSS in 2002, Nebraska understood that it would have to significantly reduce consumption of Republican River water to achieve Compact compliance. ${ }^{138}$ Yet, as the Special Master pointed out, Nebraska did not immediately implement the changes necessary to achieve compliance. ${ }^{139}$ Quite the contrary, while the compliance clock ticked, Nebraska waited for over a year to introduce legislation effectuating the FSS. ${ }^{140}$ Even then, the implemented measures did little to incentivize actual compliance and apparently only would have done so in years of abundant rainfall. ${ }^{141}$ In other words, "Nebraska's compliance efforts [were]... inadequate and reluctant... with a hesitance to take firm action ... sufficient to meet the challenges of foreseeably varying conditions in the Basin." "142 Under these circumstances, the Master found Nebraska had "knowingly exposed Kansas to a substantial risk" that it would not receive its apportioned water, and thus found Nebraska had "knowingly failed" to comply with the Compact. ${ }^{143}$ This "knowing breach," in the Special Master's view, supported a disgorgement finding. ${ }^{144}$

\footnotetext{
133. Republican Report, supra note 7, at 176.

134. Id. at 177 .

135. Id. at $177-78$

136. Id. at 179; Kansas, $135 \mathrm{~S}$. Ct. at 1059 ("Truth be told, we cannot be sure why the Master selected the exact number he did — why, that is, he arrived at $\$ 1.8$ million, rather than a little more or a little less.").

137. Republican Report, supra note 7, at 105-12.

138. Id. at 106 .

139. Id. at $106-07$.

140. Id. at $107-08$.

141. Id. at 108-11. Once implemented, Nebraska called for only a five percent decrease in consumption, though no evidence suggested this reduction would be sufficient. Id. at 107-08.

142. Id. at 105 .

143. Id. at 130,112 .

144. Id. at 130 .
} 
Despite this "knowing breach," the Special Master presented two reasons for why a greater disgorgement award against Nebraska was not necessary. First, though he found that Nebraska had "knowingly exposed Kansas to a substantial risk that Nebraska's compliance measures would not ensure compliance," he reasoned that Nebraska had not deliberately breached the Compact. ${ }^{145}$ Second, he pointed to the numerous compliance steps taken by Nebraska after 2007, which, in the Master's mind, showed Nebraska could effectively comply in the future. ${ }^{146}$ Together with the fact that the present case constituted Nebraska's first Compact breach, the Master concluded that only a slight disgorgement should be awarded. ${ }^{147}$ Absent these factors, however, the Special Master noted there would be little to prevent a larger disgorgement award. ${ }^{148}$

\section{b. Kansas's Exceptions: More Disgorgement, Please}

Kansas agreed with the Special Master's disgorgement finding, but took exception to the amount (as well as other findings not important to this writing). ${ }^{149}$ Kansas argued that the unique nature of water compacts makes disgorgement a vital remedy, because states in similar agreements do not have the ability to replace wrongly taken water. ${ }^{150}$ Kansas further argued that Nebraska should pay a "significant" disgorgement award of $\$ 11.1$ million (triple the expectation damages) and took exception to the Master's minimal disgorgement finding. ${ }^{151}$ Kansas presented four separate arguments in support of a disgorgement award: (1) opportunistic breach of contract, (2) violation of federal statute, (3) equitable conversion, and (4) breach of fiduciary duty. ${ }^{152}$

The present case resembled an opportunistic breach of contract scenario, Kansas argued, because the Special Master found Nebraska had knowingly breached the Compact. ${ }^{153}$ Moreover, Kansas reasoned that

\footnotetext{
145. Id. at 130,179 .

146. Id. at $112-19,180$.

147. Id. at $179-80$.

148. Id.

149. Kansas Exceptions, supra note 98, at i.

150. Id. at 48 .

151. Id. at 53-57. In total, Kansas actually presented three separate disgorgement amounts: $\$ 11.1$ million (three times the expectation damages), up to $\$ 25$ million (the approximate profit the Special Master attributed to Nebraska), and \$3.7 million (equal to Kansas's expectation damages). Kansas v. Nebraska, 135 S. Ct. 1042, 1058 (2015).

152. Kansas Exceptions, supra note 98, at 47-50.

153. Id. at 47 .
} 
disgorgement would provide stability to the Compact, particularly because Nebraska had apparently gained far more than Kansas lost. ${ }^{154}$ Kansas also argued that, because water and water rights are property, a breach of the Compact was akin to the taking of property, and thus constituted equitable conversion. ${ }^{155}$ Finally, the state noted that the present scenario resembled a breach of fiduciary duty, though not in fact, because Kansas relied on Nebraska to ensure the proper amount of water passed downstream. ${ }^{156}$ Nebraska thus was required to "manage the use of water in the Basin in part for the benefit of Kansas."

\section{c. Nebraska's Exceptions: No Legal Precedent}

Nebraska took exception to the Special Master's disgorgement finding, arguing, among other things, that contract law made no provision for disgorgement damages, that no legal precedent existed for disgorgement in water disputes, and that an "incentive" would be unnecessary given the state's recent compliance measures. ${ }^{158}$ The state pointed to section thirty-nine of the Restatement (Third) of Restitution and Unjust Enrichment, arguing that because it had not "deliberately" breached the Compact, disgorgement was not applicable. ${ }^{159}$ Quite apart from the hesitance described in the Special Master's report, Nebraska argued that it had taken "extraordinary" steps to assure Compact compliance. ${ }^{160}$ Additionally, the state urged that it could not have foreseen that its measures would not ensure compliance during the drought years of 2002-2006. ${ }^{161}$

In its amicus brief to the Supreme Court, the United States essentially endorsed all findings of the Special Master. The United States pointed out the adverse consequences of efficient-or opportunistic - breach in interstate water cases. ${ }^{162}$ Without a proper incentive, the Government argued, upstream states would breach water

\footnotetext{
154. Id. at $47-48$.

155. Id. at $50-51$.

156. Id. at 52 .

157. Id

158. Nebraska's Exceptions and Brief in Support at 11-18, Kansas v. Nebraska, 135 S. Ct. 1042 (2015), No. 126 (Feb. 27, 2014), http://www.americanbar.org/content/dam/aba/publications/ supreme_court_preview/BriefsV4/Orig_126_nebraska_exceptions_brief_support.authcheckdam.pdf.

159. Id. at 16 .

160. Id. at 9,17 .

161. Id. at 17 .

162. Brief of the United States as Amicus Curiae in Support of Overruling the Parties' Exceptions to the Report of the Special Master at 3, 17, Kansas v. Nebraska, 135 S. Ct. 1042 (2015), No. 126 (Apr. 7, 2014), 2014 WL 7717723.
} 
compacts so long as their profits exceeded the losses accrued by downstream states. ${ }^{163}$ Disgorgement would protect a state's legal right to the correct amount of water and dissuade future breaches by upstream states. ${ }^{164}$

\section{d. The Supreme Court's Decision: Tough Justice (Sort Of)}

In a six-three decision delivered by Justice Kagan, the Supreme Court summarily accepted the Special Master's findings on disgorgement and agreed that Nebraska had "knowingly" failed to comply with the Compact. ${ }^{165}$ The Court presented two distinct rationales for its application of disgorgement. First, the Court asserted its equitable authority "to remedy violations of and promote compliance with" an interstate compact. ${ }^{166}$ Second, the Court noted that the peculiar nature of interstate water compacts merited a more extraordinary remedy than those traditionally available for breaches of contract. ${ }^{167}$ These two rationales will be examined in turn.

From an equitable perspective, the Court cited its "inherent authority, as part of the Constitution's grant of original jurisdiction, to equitably apportion interstate streams between States." 168 Such authority meant it was (and is) well within the Court's power to stop states from taking an unfair amount of water. ${ }^{169}$ As for compacts, the Court cited its authority to enforce interstate compacts and formulate fair remedies within the scope of the compact in question. ${ }^{170}$ Additionally, the Court asserted that it "may 'mould each decree to the necessities of the particular case' and 'accord full justice' to all parties." 171

With this language in place, the majority next found that it was well within the Court's authority to apply disgorgement against a state that had breached its water compact. ${ }^{172}$ In doing so, the Court set much by the upstream-downstream dynamic that necessarily plays a part in any compact allocating water between states. ${ }^{173}$ As an upstream state,

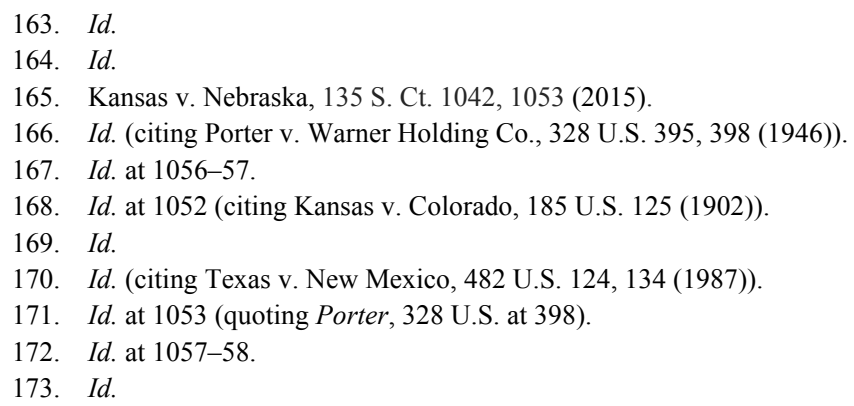


Nebraska possessed a decided advantage when it came to Compact compliance, since the state could take whatever water it wanted from the Republican River. ${ }^{174}$ This upstream position, coupled with the value of water (a "scarce natural resource"), ${ }^{175}$ created a chance for opportunistic breach that Nebraska simply could not resist. ${ }^{176}$ Under these circumstances, the Court felt that "a disgorgement award [would] appropriately remind[] Nebraska of its legal obligations, deter[] future violations, and promote[] the Compact's successful administration."177 In other words, the Court found that disgorgement would properly incentivize future compliance with the Compact.

The Court also agreed with the Special Master that a greater disgorgement award was not necessary in the present case. ${ }^{178}$ Relying on the Special Master's findings, the Court pointed to the steps Nebraska had taken since its breach in 2005-2006. ${ }^{179}$ The change in Nebraska's compliance steps since that time assured the Court - as it had assured the Special Master - that Nebraska did not need a harder kick than the one already received. ${ }^{180}$ Partial disgorgement adequately stabilized the Compact by informing Nebraska of its duty to comply in the future; as such, the Court did not see any reason to apply a higher amount. ${ }^{181}$

\section{ANALYSIS}

The Special Master's findings, while reasonable, gave more credit to Nebraska than was due. For instance, the Master overlooked the fact that Nebraska's breach was not in fact the state's first breach of the Compact. Though Nebraska maintained the contrary, the Special Master in the first round of Kansas v. Nebraska found the Compact clearly applied to groundwater pumping and that Nebraska was in breach of that provision. ${ }^{182}$ Moreover, the Special Master in this recent case ignored the fact that 2007 and the years beyond were, generally speaking, years of above-average rainfall in the Republican River Basin, while the years in dispute were years of exceptional drought. ${ }^{183}$ An abundance of rainfall

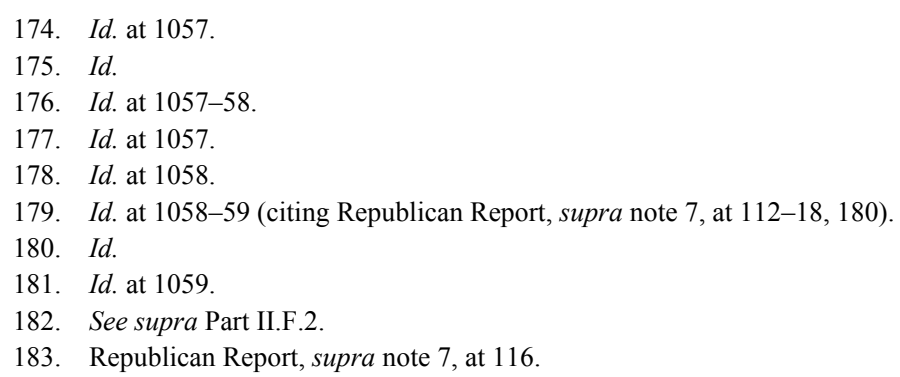


would almost certainly guarantee compliance - it is the water-short years that are the worry.

Despite this oversight, the Special Master's - and, by extension, the Supreme Court's-decision to not apply full disgorgement against Nebraska was the proper one. Given the importance of water, a damage award like disgorgement should always be available as an incentive against future breaches. Indeed, expectation damages alone give very little incentive for compliance, especially when potential profits far exceed the damages a state would have to pay. ${ }^{184}$ However, disgorgement ought to be applied on a sliding scale, not an all-or-nothing basis. The Special Master's findings wisely account for the fact that not all breaches are the same. Several factors, then, ought to be considered when determining the extent to which a state must part with its profits. This analysis first presents reasons why, as the Supreme Court rightly found, disgorgement is the proper remedy for interstate water disputes, and then provides several factors with which a special master-or the Supreme Court-may calculate the proper size of the disgorgement award.

\section{A. Disgorgement Is a Proper Remedy for the Breach of an Interstate Water Compact}

Interstate water compacts occupy a peculiar place in the legal context. The agreements could be deemed contracts, federal law, or both. What is evident is that these compacts do not resemble the typical contract situation, nor do they entirely differ from such cases. Thus, as the Court found, the general lack of legal precedent for disgorgement remedies in interstate water disputes should not be a major concern. ${ }^{185}$

Water compacts regulate the use of what can only be called an essential resource. This alone distinguishes these compact violations from any other breach of contract situation. Water cannot be replaced, and in the case of Kansas, it cannot be purchased elsewhere absent enormous costs. Concern then should not be with the novelty of the disgorgement remedy, but rather with the possibility that a state's breach could deprive another state of a vital resource.

Part A of this analysis agrees with the Supreme Court that disgorgement is a proper remedy consideration for breaches of interstate

184. See supra Part II.D.4; Kansas, 135 S. Ct. at 1057 ("[T]he higher value of [Republican River] water [to] Nebraska than [to] Kansas[] means that Nebraska [could] take water that under the Compact should go to Kansas, pay Kansas actual damages, and still come out ahead.").

185. See supra Part II.F.2.d. 
water compacts. Specifically, the first section asserts that the vital nature of water should be the primary rationale for a stronger remedy in interstate water cases, and also notes that the very possibility of disgorgement would ensure compact compliance. Next, the second section explains that expectation damages alone are insufficient to ensure compact compliance, because the profits gained by a breaching state often exceed the losses of a plaintiff state by a large margin, and, additionally, incentivize bad faith contract negotiations.

1. Water Is a Vital Resource, and Thus Any Damage Award for the Breach of an Interstate Compact Should Be Sufficient to Ensure Future Compliance

Given its vital importance in the lives and livelihoods of everyone, water occupies a unique area in the law and contracts especially. ${ }^{186}$ Water compacts govern the apportionment of a vital resource. A lack of this resource could, and often does, have severe consequences. Because water is so important to states and their citizens, water compacts ought to be subject to damages more stringent than expectation costs in the event of a breach. While the general goal of remedies is merely to make a party whole, ${ }^{187}$ the importance of water and states' interests in obtaining their agreed-upon share gives rise to a situation in which damages should not only make a non-breaching party whole, but punish the breaching party as well. ${ }^{188}$

The possibility of disgorgement also serves as an incentive for states to ensure full compliance with a compact. ${ }^{189}$ As noted by the Special Master and the Supreme Court in round two of Kansas v. Nebraska, Nebraska took steps to regulate its local water districts in an effort to comply with the Republican River Compact. ${ }^{190}$ The possibility of some legal action possibly compelled Nebraska to take these steps-though notably, not until after it had breached its water compact with Kansas. ${ }^{191}$ Disgorgement as a remedy for breaches serves as an extra incentive to

186. In the words of Albert Szent-Gyorgyi, "Water is life's matter and matrix, mother and medium. There is no life without water." Albert Szent-Gyorgyi Quotes, BRAINY QUOTE, http://www.brainyquote.com/quotes/quotes/a/albertszen385453.html (last visited May 24, 2015).

187. See DoBBS, supra note 9.

188. See supra Part II.F.3.b; Kansas, 135 S. Ct. at 1057 ("[W]hatever is true of a private contract action, the case for disgorgement becomes still stronger when one State gambles with another State's rights to a scarce natural resource.").

189. See supra Part II.D.4.

190. Kansas, 135 S. Ct. at 1058-59; Republican Report, supra note 7, at 112-19, 180.

191. Republican Report, supra note 7, at 112. 
comply fully with a water compact. ${ }^{192}$ While taking the form of a stick, rather than a carrot, disgorgement would nevertheless compel states to take positive steps toward compliance. Moreover, if a state somehow found it impossible to comply, the threat of disgorgement would serve as a motivator to negotiate a new compact, rather than simply allow a breach to occur. ${ }^{193}$

\section{Expectation Damages Alone Are Not Sufficient to Ensure Compliance}

While expectation damages may be the common remedy for a breach of contract, ${ }^{194}$ they are an insufficient remedy for interstate water compact breaches. Although a non-breaching state would be compensated for its loss, there remains the possibility that a state would opportunistically breach a compact with the knowledge that any loss in damages would be outweighed by the profits obtained. ${ }^{195}$ The incentive, then, would be for a state to negotiate a lower water apportionment, only to breach the compact and pay the damages resulting from the state's overuse (in other words, bad faith contract negotiations). ${ }^{196}$ And indeed, the Supreme Court found this very situation existed in the Republican River Compact. ${ }^{197}$

In Kansas v. Nebraska, Nebraska's calculated profits resulting from its breach ranged between $\$ 25$ million and $\$ 55$ million, while damages to Kansas from the breach were $\$ 5.5$ million at most. ${ }^{198}$ Applying the theory of efficient breach, Nebraska — at the very least—received a profit of $\$ 19.5$ million, ${ }^{199}$ and very possibly more. Viewing these numbers in the context of efficient breach theory, Nebraska would have every reason to continue breaching the Compact with Kansas, provided Nebraska's

\footnotetext{
192. See supra Part III.F.3.d.

193. See Restatement (ThiRd) OF Restitution AND Unjust EnRichment $§ 39 \mathrm{cmt}$. b (2011); Kull, supra note 10, at 2050.

194. See supra note 57 and accompanying text.

195. Kansas Exceptions, supra note 98, at 47 (citing Nebraska's argument that the "Compact should be treated as an ordinary commercial contract, one that Nebraska can breach whenever it is economically advantageous for Nebraska to do so"); see supra note 163 and accompanying text.

196. Kansas Exceptions, supra note 98, at 47-48.

197. Kansas v. Nebraska, 135 S. Ct. 1042, 1057 (2015).

198. Republican Report, supra note 7, at 177-79.

199. This figure is Nebraska's estimated net profit if one assumes Nebraska gained $\$ 25$ million from its breach and incurred $\$ 5.5$ million in expectation damages (that is, $\$ 25$ million less $\$ 5.5$ million).
} 
profits continue to exceed the losses sustained by Kansas (and thus, the expectation damages owed). ${ }^{200}$

This scenario mirrors the opportunistic breach example presented above in which a party breaches by doing precisely what it has contracted not to do. ${ }^{201}$ The case of the Republican River Compact is strikingly similar. The Compact is, in essence, an agreement between three states to not use too much water, or rather a promise by Nebraskaand Colorado - to leave water in the Republican River for Kansas to use. ${ }^{202}$ When Nebraska exceeds its allocated share and breaches the Compact, it has done exactly what it explicitly agreed it would not do. ${ }^{203}$ There is certainly a profit in breach for Nebraska, as the Special Master's findings indicate, but should these profit motives outweigh the very essence of the Compact? The Supreme Court thought not. ${ }^{204}$

Disgorgement eliminates any profit motive to breach and thereby stabilizes water compacts everywhere. ${ }^{205}$ Even if one eliminates a distinguishable profit motive, disgorgement still would provide the incentive to comply in all situations, not just when the weather is good or litigation appears imminent. ${ }^{206}$ Applying disgorgement on a sliding scale dependent on the circumstances of a state's breach could easily nullify any potential unfairness to a defendant state and still provide the adequate incentive to comply with an interstate water compact.

\section{B. Disgorgement, Though Proper for a Breach of Water Compact, Should Be Applied on a Sliding Scale, Taking Several Factors into Account}

Even though disgorgement is a proper remedy for the breach of an interstate water compact, full disgorgement runs the risk of going too far, or penalizing too much. The extent to which disgorgement is applied ought to depend on a number of factors that arise from the facts of each case: (1) the duration of the breach, (2) the size or severity of the breach, (3) repetitious breach, (4) a state's response to the breach, and (5) a good faith versus bad faith analysis. By weighing these factors against each

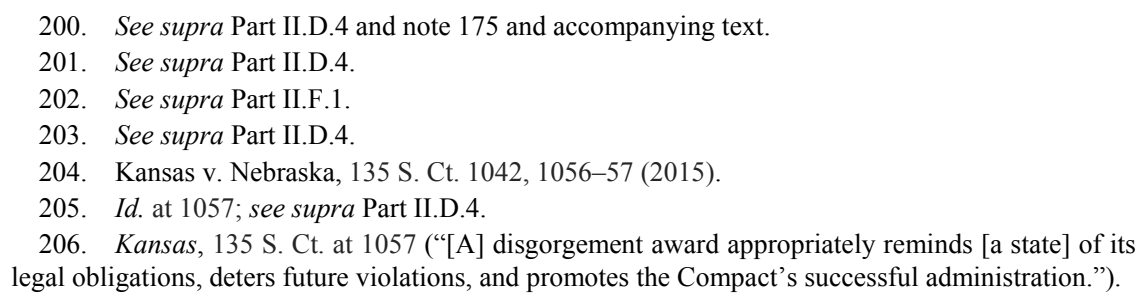


other, a special master - and, by extension, the Supreme Court - could determine the extent of disgorgement on a case-by-case analysis and thereby avoid potentially disastrous consequences to upstream states.

1. If Full Disgorgement Were Applied to Breaches of Interstate Water Compacts, the Results Could Be Potentially Catastrophic for Upstream States

According to the Restatement (Third) of Restitution and Unjust Enrichment, disgorgement, when applied, should be applied in full. ${ }^{207}$ Applied to a breach of interstate water compact case, full disgorgement would strip a state of all ill-gotten gains resulting from its breach of the compact. Using Kansas v. Nebraska as an example, full disgorgement would have required Nebraska to pay anywhere between $\$ 25$ million and \$55 million to Kansas in disgorgement damages, regardless of the length, severity, or Nebraska's response to the breach. ${ }^{208}$

The full disgorgement approach disregards the nuances of each individual case, and instead seems to recommend a machete in cases where a scalpel would be better suited. There is an inherent unfairness in assessing what could be a costly penalty on states that have committed only minor compact breaches. And, as the Supreme Court found, there is no reason to apply a higher disgorgement award if a lighter award achieves the same ends (that is, future compact compliance). ${ }^{209}$ With full disgorgement, relatively minor breaches could cost upstream states tens of millions of dollars and major breaches well beyond even that amount.

Beyond the plain unfairness of the full disgorgement approach, there are concerns about its potentially disastrous consequences to upstream states. $^{210}$ For its part, Colorado is an upstream state not only for the Republican River, but also the Colorado, Platte, and Arkansas Rivers (to name a few). ${ }^{211}$ Application of full disgorgement could subject upstream states like Colorado to large judgments every time they breach a water compact. And, if Colorado were found to have breached more than one of its water compacts in a given year, the state might face enormously

\footnotetext{
207. RESTATEMENT (THIRD) OF RESTITUTION AND UNJUST ENRICHMENT $§ 39 \mathrm{cmt}$ c c (2011).

208. Republican Report, supra note 7, at 138, 177-78.

209. Kansas, 135 S. Ct. at 1058-59.

210. Colorado's Exception to the Report of the Special Master and Brief in Support of Exception at 9-10, Kansas v. Nebraska, 135 S. Ct. 1042 (2015), No. 126 (Feb. 27, 2014), http://www.americanbar.org/content/dam/aba/publications/supreme_court_preview/BriefsV4/Orig12 6_colorado_exception.authcheckdam.pdf.

211. Colorado Geography, WORLD ATLAS, http://www.worldatlas.com/webimage/countrys /namerica/usstates/coland.htm (last visited May 24, 2015).
} 
burdensome judgments that could seriously encroach on other state interests.

A disgorgement award should match the magnitude of the breach. If a state commits an enormous breach, full disgorgement, of course, could be the proper remedy. If, however, a state like Colorado commits only minor breaches, then full disgorgement would be highly unjust given the circumstances. Disgorgement should incentivize compact performance as nearly as possible, but it should not serve as a deterrent from creating a compact in the first place. Faced with the possibility of full disgorgement, no matter how large or small its breach, states like Colorado would potentially opt for a pure litigation approach to water apportionment. Disgorgement should aid the enforcement of water compacts, not serve as a reason not to make them.

Though the threat of disgorgement damages should provide an incentive for states to adhere to their water compacts, the penalty should fit the crime- that is, the extent of the breach. This qualifier is not meant to argue that full disgorgement should never apply; rather, the trier of fact should assess certain factors in each individual case to determine the extent of disgorgement damages.

2. Disgorgement Applied on a Sliding Scale Would Allow the Court or a Special Master to Fix Damages on a Case-by-Case Basis, Taking Several Factors into Account

In his assessment of the damages owed by Nebraska, the Special Master in Kansas v. Nebraska found Nebraska owed only \$1.8 million in disgorgement damages, even though its profits were estimated between $\$ 25$ million and $\$ 55$ million. ${ }^{212}$ To support this finding, the Special Master cited Nebraska's newly-initiated compliance programs following the breach, which, both the Special Master and the Supreme Court thought, demonstrated the state's intent to comply with its Compact obligations and precluded any finding of bad faith. ${ }^{213}$

Of equal importance, the Special Master noted that the case at hand constituted the "first judgment of breach against Nebraska under [the Republican River] Compact," 214 though he took care to mention that future breaches of the Compact by Nebraska would be treated

212. Republican Report, supra note 7, at 179-80.

213. Id.; Kansas, 135 S. Ct. at 1058-59.

214. Republican Report, supra note 7, at 180. 
differently. ${ }^{215}$ These findings acknowledge the need to apply disgorgement damages on a sliding scale, contingent on five factors: (1) the duration of the breach, (2) the size or severity of the breach, (3) repetition of the breach, (4) the state's response to its breach, and (5) a finding of good faith or bad faith. ${ }^{216}$ These five factors would provide a special master and the Court with a continuum on which to base disgorgement damages, with heavier penalties for major breaches and lighter penalties for minor breaches. The factors should be weighed against each other to aid an assessment of disgorgement damages, and should each be measured individually based on the facts of the case.

\section{a. Duration of the Breach}

The first significant factor is the duration of the breach, that is, the number of years the state breached the water compact. This factor would most directly apply to compacts that measure compliance on a year-toyear basis. For such compacts, the number of years spent in noncompliance would favor either a larger or smaller disgorgement judgment. For example, if a state has breached a compact for twenty years, that fact would weigh in favor of finding greater disgorgement damages, while a breach of one year would weigh in favor of minimal disgorgement.

For agreements like the Republican River Compact, which measure compliance through compliance periods, ${ }^{217}$ duration would not merit as much consideration simply because compliance is averaged over a specified period of time. ${ }^{218}$ By nature, these compliance periods are meant to give states time to offset years in excess of their allocated water amount with years below their allocated amount. ${ }^{219}$ Thus, the focus of these periods is not so much the number of years in breach as it is the size or severity of the breach.

\footnotetext{
215. Id.

216. I have based these five factors on my understanding of the Special Master's findings. Based on these findings, I derived five factors that appeared to inform the Master's decisions, even if he did not expressly acknowledge them.

217. See supra Part II.F.2.

218. Republican Report, supra note 7, at 8.

219. Id.
} 
b. Size or Severity of the Breach

The size or severity of the breach is likely the most important factor for consideration. As the factor indicates, the Court or a special master would consider the amount by which a state has exceeded its allocated share of water. Here, as with duration, the individual facts of the case and the state's allocated share would determine the extent of the breach. Disgorgement would then be applied based on the egregiousness of the breach. Thus, if a state has exceeded its allocated share by fifty percent, higher disgorgement would be proper. If, on the other hand, the state has exceeded its allocated share by only one percent, lower disgorgement would be proper.

Though the severity of a breach would be weighed against the other four factors in this test, it should be assigned a greater weight. After all, it is the overuse of water that leads to disputes between states. ${ }^{220}$ A state that breaches its compact only one year should still pay higher disgorgement damages if water use during that year far exceeded the state's allocated amount. In a case like Kansas v. Nebraska, a state that has exceeded its contracted amount after the five-year compliance period should pay disgorgement in proportion to the severity of its breach. These examples are meant to highlight the importance of this factor while considering the amount of applicable disgorgement damages. Though other factors may be neutral, or weigh in favor of a breaching state, those factors should at least be offset if a state has exceeded its allocated share by a significant amount. The Court or a special master should therefore lend greater weight to the severity of a breach when weighing these factors.

\section{c. Repetitious Breach}

The next factor to consider is the number of times a state has breached the water compact: repetitious breach. In his report, the Special Master for Kansas v. Nebraska noted the case at hand was the "first judgment of breach against Nebraska under the [Republican River] Compact." 221 This fact, according to the Special Master, precluded a finding of greater disgorgement damages. ${ }^{222}$ However, the Special

\footnotetext{
220. See supra Part II.E-F.

221. Republican Report, supra note 7, at 180.

222. Id.
} 
Master went on to note that a future breach of the Compact by Nebraska would not receive the same lenient treatment. ${ }^{223}$

A special master or the Court should follow this same line of reasoning for future breach of compact cases. As a matter of fairness, punishment to repeat offenders should be greater than for first time offenders, unless the first time offender has committed a major breach. In that case, the disgorgement award should be great. Anyone applying this factor should look at a state's compliance history. If, from this history, it is clear the state has breached the water compact several times before and will apparently continue to do so in the future, then higher disgorgement damages would be proper. On the other hand, if the current case is the first and only instance of breach, as the Special Master found with Nebraska, ${ }^{224}$ the disgorgement damages should be lower.

Of course, this factor should also be viewed in conjunction with the severity of the breach. Several minor breaches are different from a single, major breach. A single, major breach of a water compact may be more significant than multiple, smaller breaches. Then again, multiple breaches by a state should weigh in favor of higher disgorgement damages, no matter how small. A single breach-whether major or minor-should alert a state of the need to better ensure future compliance. Multiple breaches, then, would tend to show that the state is either not serious about compliance, or needs a greater incentive to achieve compliance.

If the state does not seem serious about compliance, a higher disgorgement penalty would punish the state's lack of good faith. If the state merely needs a shot in the arm, so to speak, disgorgement would provide an incentive for the state to achieve compact compliance, lest it pay an even higher penalty in the future. This factor, then, would often be contingent on a state's response once it is made aware of a breach.

\section{d. State's Response to a Breach}

A state's response to its breach of a compact is another factor to consider. This factor would be of particular importance when assessing the good or bad faith of a state. Indeed, Nebraska's response following its breach of the Republican River Compact was a point of particular emphasis in the Special Master's report. ${ }^{225}$ The Special Master cited

\footnotetext{
223. Id. at 183 .

224. Id. at $179-80$.

225. Id. at 179 .
} 
Nebraska's "substantial expenditures" in the years following its breach of the Compact as evidence that the state held the sincere intention to comply with the Compact, and had acted upon that intention through positive steps. ${ }^{226}$ These steps, by and large, included a new regulatory scheme aimed at greater compliance. ${ }^{227}$ The Special Master was careful to note, however, that, absent these actions, "it would be difficult not to order a more substantial disgorgement of any gain." 228 Therefore, a state's actions after it is made aware of a breach should influence a disgorgement award.

If a state is made aware of a breach and does nothing in response, that should lead to a greater disgorgement finding, since the state clearly does not take its obligations seriously enough. Conversely, a state that, like Nebraska, spends extra money on compliance should be viewed in a more positive light and assessed a smaller disgorgement penalty. Repetition of breach also becomes an important consideration for this factor, since the more repetitious the breach, the more likely it is that a state is not taking compliance seriously, or at least not making adequate efforts to comply with the compact. By definition, a state's repeated breaches of a compact are evidence the state has not made a concerted effort to comply, at which point the good faith-bad faith factor comes into consideration.

\section{e. Good Faith Versus Bad Faith}

Good faith or bad faith would not relate to a state's breach of the water compact; rather, the analysis would review the state's overall approach to compliance. The Special Master in Kansas v. Nebraska stated that Nebraska's noncompliance was not the result of some malicious plot to get more water, but merely good intentions poorly executed. ${ }^{229}$ The same analysis should apply to other cases of noncompliance. A state that, on the evidence, appears to have made a good faith effort to comply with the water compact should not be penalized as heavily as a state that clearly displayed no intention to comply.

More than any other factor, good faith-bad faith relies heavily on the other factors in this test. A state's intentions can be indicated by the duration, severity, and repetition of its breach, as well as the state's

226. Id.

227. Id. at $112-19,180$.

228. Id. at 179

229. Id. 
response once the breach comes to light. The more factors that weigh unfavorably against a breaching state, the more likely it is the state has made the compact in bad faith - that is, the more likely the state never intended to comply. For instance, a state that has breached a compact multiple times over many years with usage well in excess of its apportioned amount, all without ever taking steps toward compliance, should almost assuredly be found to have made the compact in bad faith. In such a situation, hefty_-even full-disgorgement would be a proper penalty. One can imagine the opposite holding true as well. Of course, the facts of cases will vary from these two extremes. It would therefore be up to the discretion of the special master or the Court to determine whether the facts, taken as a whole, indicate good faith or bad faith compliance with a water compact.

f. Weighing the Factors

The factors stated above create the context in which to assess damages. Disgorgement determinations should not be based on one factor alone, unless of course one factor clearly shows a hefty disgorgement penalty is proper. As with any factors test, the factors here should be weighed against each other in the context of each case. Certain factors, like severity of breach, may hold greater weight overall, but each factor threads through the others. A finding as to one factor could very well influence the finding for another.

\section{CONCLUSION}

In a perfect world, upstream states would take only what they agreed to take and leave the rest to their downstream neighbors. However, their positions upriver necessarily mean upstream states do not have the same interest in compact compliance as downstream states. An upstream state has the decided benefit of not feeling the adverse consequences of its decision to take more than its allocated share. If the resource in question were less valuable - or vital-perhaps this fact would not be so important. ${ }^{230}$ As it is, an upstream state that breaches a water compact stands only to benefit from its breach, while a downstream neighbor can only be harmed by it. If expectation damages were the only available remedy, an upstream state could simply take more than its allotted share

230. See supra Part III.A.1. 
and pay the requisite damages, even while its profits from the breach exceed the losses sustained by its downstream neighbor. ${ }^{231}$

As the Special Master noted in Kansas v. Nebraska, such opportunistic breaches of water compacts would provide the perverse incentive for an upstream state to make a compact without the intention to adhere to it. ${ }^{232}$ Actions of this kind would be fundamentally against the entire point of contracts. Parties (or states) who enter into a contract should adhere to that contract. Particularly in the realm of water-the most vital of resources - it would be bad policy to allow states to breach their negotiated compacts simply because they stand to gain more than a downstream neighbor would lose.

Thus, disgorgement is a proper remedy for the breach of an interstate water compact. ${ }^{233}$ The threat that a breach would not only result in expectation damages, but a loss in profits as well, would sufficiently dissuade a state from committing breaches in the future. ${ }^{234}$ Despite disgorgement's potential severity, water's status as a vital and irreplaceable natural resource necessitates a stronger measure than usual for noncompliance with an interstate compact.

Water compacts should be negotiated, and states should be held to those negotiations. If a state wants - or needs - more water, it should negotiate with its counterparts. If, on the other hand, a state breaches, it should be disgorged of at least some of the profits related to that breach to incentivize future compliance. Disgorgement would thus serve the dual purpose in a water compact as both a stabilizing force and an incentive to comply in the future. ${ }^{235}$

However, disgorgement should be applied on a factor-based sliding scale and courts should use a case-by-case analysis. ${ }^{236}$ To do otherwise would unjustly penalize states that have committed only minor breaches. After all, disgorgement should be an incentive to comply with a compact, not an incentive to make no compact at all. The five-factor approach described above takes the nuances of each individual case into account and also limits any potential adverse consequences that might arise from applying full disgorgement to every breach.

231. See supra Part II.D.4.

232. Republican Report, supra note 7, at 103-12.

233. See supra Part III.A.

234. See Restatement (ThiRd) of Restitution And UnJust EnRichment $\S 39 \mathrm{cmt}$. b (2011); Kull, supra note 10, at 2050.

235. See supra Part III.A.2.

236. See supra Part III.B. 
Ultimately, the goal of disgorgement is to ensure the fair apportionment of a vital resource. The remedy stands for the principles that negotiations should be made in good faith and that negotiating states should adhere to their promises. A system in which such principles did not hold would encourage states to make false promises that would ultimately leave their neighbors out to dry. 